\title{
KECERNAAN RANSUM SAPI BALI DENGAN KONSENTRAT FERMENTASI BERBASIS LUMPUR SAWIT DAN BAHAN PAKAN LOKAL
}

\section{DIGESTIBILITY OF BALI CATTLE DIET WITH FERMENTED CONCENTRATE BASED ON SOLID AND LOCAL FEED}

\author{
Irma Badarina ${ }^{1}$, Jarmuji, Dodi Permadi Gultom \\ Jurusan Peternakan Fakultas Pertanian Universitas Bengkulu \\ Email: ${ }^{1}$ ibadarina@yahoo.com
}

\begin{abstract}
The aim of this research was to evaluate the dry matter and organic matter digestibility in vivo of Bali cattle diet that supplemented with fermented concentrate ration based from palm oil sludge and several local feed sources. Fifteen Bali cattles with 2 years old and the range of live weight 184,5 $\pm 3,63 \mathrm{~kg}$ were distributed into three treatments and five replication in Completely Randomized design. The treatment was the level of concentrate supplementation, They were P1 (10kg/day), P2(7,5kg/day) and P3(5kg/day). The forage and the rice straw were adjusted as much as $10 \mathrm{~kg} /$ day and $1 \mathrm{~kg} /$ day, respectively. The composition of fermented concentrate consisted of palm oil sludge (70\%), rice bran (10\%), coffee husk (10\% )and coconut press fiber (10\%). As bioactivator used"Bionak"as much as 0,3\%. The an aerob fermentation took time a week. The result showed that up to the highest level (10kg/day) the supplementation of fermented concentrate ration enhanced the consumption and the digestibility of the whole rations.
\end{abstract}

Keywords: digestibility, concentrate, palm oil sludge, fermentation, cattle.

\begin{abstract}
ABSTRAK
Penelitian ini bertujuan untuk mengevaluasi kecernaan bahan kering dan bahan organik in vivo ransum sapi Bali dengan suplementasi pakan konsentrat yang telah difermentasi berbasis lumpur sawit dan beberapa bahan pakan lokal. Satuan percobaan adalah 15 ekor sapi Bali jantan berumur seragam yaitu dua tahun dan bobot badan $184,5 \pm 3,63 \mathrm{~kg}$ yang didistribusikan pada tiga perlakuan dengan lima ulangan. Rancangan percobaan menggunakan Rancangan Acak Lengkap. Perlakuan adalah level pemberian pakan konsentrat yaitu P1 (10 kg/ekor/hari), P2 (7,5kg/ekor/hari) dan P3(5 kg/ekor/hari). Pakan hijauan dan jerami padi masing-masing diberikan sebanyak 10 $\mathrm{kg} / \mathrm{ekor} / \mathrm{hari}$ dan $1 \mathrm{~kg} / \mathrm{ekor} / \mathrm{hari}$. Komposisi pakan konsentrat fermentasi terdiri dari lumpur sawit (solid) $70 \%$, dedak 10\%, kulit buah kopi 10\%, dan ampas kelapa 10\%. Sebagai bioaktivator digunakan "Bionak" sebanyak 0,3\% kemudian difermentasi anaerob selama seminggu. Hasil penelitian menunjukkan bahwa pemberian pakan konsentrat berbasis lumpur sawit dan beberapa bahan pakan local fermentasi sampai taraf tertinggi yaitu $10 \mathrm{~kg} /$ ekor/hari meningkatkan konsumsi dan kecernaan ransum.
\end{abstract}

Kata kunci: kecernaan, konsentrat, lumpur sawit, fermentasi, sapi 


\section{PENDAHULUAN}

Konsumsi daging sapi di Indonesia berdasarkan data Survei Sosial Ekonomi Nasional (SuSeNas) tahun 2014 adalah 2.08 $\mathrm{kg} / \mathrm{kapita} / \mathrm{tahun}$. Angka ini tergolong kecil dibandingkan dengan konsumsi negara maju. Tingkat konsumsi yang rendah ini diduga karena adanya kesenjangan dengan suplai daging sapi. Suplai daging lebih rendah dari kebutuhan sehingga harga daging menjadi mahal. Oleh sebab itu perlu dilakukan upaya untuk meningkatkan suplai daging sapi antara lain dengan meningkatkan populasi dan produktivitas ternak sapi potong di Indonesia. Peningkatan produktivitas sapi diharapkan akan mensukseskan program "Swasembada Daging Sapi".

Performa produksi ternak yang baik dapat dicapai dengan penyediaan pakan yang cukup kuantitas dan kualitasnya. Masalah yang sering dijumpai adalah ketersediaan hijauan yang semakin sulit. Selain itu harga komoditi bahan pakan konsentrat semakin mahal seperti jagung dan bungkil kedelai. Oleh sebab itu perlu segera dilakukan inovasi untuk memanfaatkan bahan baku lokal yang banyak tersedia, murah, kontinuitas terjamin, kandungan nutrisinya cukup memadai, aman dipakai dan tidak bersaing dengan manusia. Salah satunya yaitu pemanfaatan lumpur minyak sawit/LMS (Palm Oil Sludge), limbah kulit buah kopi, dedak dan ampas kelapa. Bahan-bahan ini diformulasi menjadi ransum konsentrat.

Luas areal dan produksi kebun sawit terus meningkat dengan pertambahan luas areal setiap tahun mencapai 4,72\% (Dirjen Perkebunan, 2014). Peningkatan luas dan produksi kelapa sawit akan meningkatkan produksi limbah (Mathius et al., 2004). Pemanfaatan limbah kelapa sawit untuk bahan pakan ternak membuka peluang pengembangan peternakan yang disebabkan karena terbatasnya lahan untuk padang penggembalaan dan lahan kultivasi tanaman hijauan pakan (Utomo dan Widjaja 2004). Kandungan protein kasar lumpur minyak sawit hampir sama dengan kandungan protein kasar dedak padi. Lekito (2002) dan Mathius et al. (2005) melaporkan kandungan zat gizi lumpur sawit yaitu protein kasar 11,94\%$12,17 \%$, serat kasar $21,15 \%-29,76 \%$, lemak
10,40\%-19,96\%, selulosa 11,42\%, hemiselulosa $18,77 \%$ dan lignin $36,40 \%$. Tingginya kandungan serat kasar dan fraksi serat (kadar lignin) merupakan kendala penggunaan LMS sebagai pakan ruminansia. Selain itu LMS dalam bentuk segar tidak tahan lama, cepat busuk sehingga ternak dikhawatirkan tidak mau mengkonsumsinya.

Fermentasi merupakan salah satu upaya untuk meningkatkan nilai gizi bahan pakan sehingga kualitas dan ketersediaan nutrien dapat ditingkatkan (Wina, 2005). Winarno (1992) menyata-kan bahwa substrat yang mengalami fermentasi biasanya memiliki nilai gizi yang lebih tinggi daripada bahan asalnya. Hal ini karena sifat katabolic dan anabolic mikroorganisme sehingga mampu memecah komponen yang lebih kompleks menjadi mudah tercerna.

Penelitian ini bertujuan untuk mengevaluasi kecernaan bahan kering dan bahan organik ransum sapi Bali yang diberi pakan konsentrat fermentasi berbasis lumpur sawit dan beberapa bahan pakan lokal. Diduga pemberian pakan konsentrat berbasis lumpur sawit fermentasi tidak mempengaruhi kecernaan bahan kering dan bahan organic ransum.

\section{METODE}

Penelitian ini dilaksanakan di dua tempat yaitu di laboratorium Peternakan Fakultas Pertanian Universitas Bengkulu untuk analisa Bahan Kering dan Bahan Organik dan Unit Pelaksana Teknis Daerah (UPTD) Perbibitan Dinas Peternakan dan Kesehatan Hewan Provinsi Bengkulu untuk percobaan kecernaan in vivo. Alat yang dibutuhkan untuk proses fermentasi antara lain kantong plastik, garpu/sendok, karet, ember/nampan, gelas ukur, blender, penyaring, timbangan, oven dan tanur. Bahan yang digunakan adalah lumpur sawit segar, kulit buah kopi kering, dedak, ampas kelapa dan biofermentor adalah "Bionak". Ternak yang digunakan adalah sapi Bali jantan berumur \pm 2 tahun sebanyak 15 ekor dengan berat badan rata-rata $184,5 \pm 3,63 \mathrm{~kg}$.

Formulasi pakan konsentrat adalah lumpur sawit segar 70\%, kulit buah kopi kering $10 \%$, dedak $10 \%$ dan ampas kelapa $10 \%$. Semua bahan pakan konsentrat dicampur merata. Setelah itu dilakukan 
penambahan bioaktivator "bionak" sebanyak $0,3 \%$, lalu diaduk rata kemudian difermentasi secara an aerob selama seminggu. Pakan konsentrat siap untuk digunakan.

Ransum yang diberikan ke ternak terdiri dari lumpur sawit fermentasi sebagai konsentrat dan hijauan berupa jerami padi dan rumput gajah. Solid diberikan pagi hari sebelum pemberian hijauan (jam 7). Jerami diberikan pada siang hari (jam 13)sebanyak 1 $\mathrm{kg} / \mathrm{ekor}$ dan rumput gajah diberikan sore hari (jam 16)sebanyak $10 \mathrm{~kg} / \mathrm{ekor}$ untuk setiap perlakuan. Koleksi data dilakukan selama satu minggu berupa data konsumsi dan data produksi feses.

Kecernaan Bahan Kering (BK) $(\%)=$

$\sum$ BK yang dikonsumsi $-\sum \mathrm{BK}$ feses

$$
\sum \text { BK yang dikonsumsi }
$$

Kecernaan Bahan Organik(BO) $(\%)=$

$\sum \mathrm{BO}$ yang dikonsumsi $-\sum \mathrm{BO}$ feses

$$
\frac{\sum B O}{\sum B \text { yang dikonsumsi }} \times 100
$$

Rancangan penelitian menggunakan Rancangan Acak Lengkap dengan tiga perlakuan dan ulangan sebanyak lima kali. Perlakuan adalah level pemberian konsentrat berbasis lumpur sawit fermentasi yaitu P1 (pemberian konsentrat sebanyak 10 $\mathrm{kg} / \mathrm{ekor} / \mathrm{hari}$ ), P2 (pemberian konsentrat sebanyak 7,5 kg/ekor/hari), dan P3(pemberian konsentrat sebanyak $5 \mathrm{~kg} / \mathrm{ekor} / \mathrm{hari})$. Data penelitian diuji keragamannya dengan ANOVA. Uji lanjut menggunakan Duncan Multiple Range Test (DMRT).

\section{HASIL DAN PEMBAHASAN}

\section{Konsumsi Bahan Kering (BK)}

Hasil konsumsi bahan kering (BK) selama penelitian disajikan pada Tabel 1 .

Berdasarkan hasil sidik ragam, perlakuan berpengaruh nyata $(\mathrm{P}<0,05)$ terhadap total konsumsi bahan kering ransum. Hasil uji lanjut menunjukkan bahwa konsumsi bahan kering ransum P1 nyata tertinggi dan masing-masing perlakuan berbeda nyata. Perlakuan P3 paling rendah
$(\mathrm{P}<0,05)$. Data pada Tabel 1 diatas memberikan informasi bahwa level pemberian konsentrat yang tinggi dapat menghemat pemberian hijauan yang ditunjukkan oleh konsumsi hijauan dan jerami yang menurun. Dengan demikian konsentrat berbasis lumpur sawit fermentasi dapat digunakan sebagai alternatif pakan untuk menghemat pemakaian hijauan terutama pada saat hijauan susah diperoleh (musim kemarau).

Tabel 1. Data konsumsi bahan kering (BK) hijauan, konsentrat dan ransum (kg/ekor/hari)

\begin{tabular}{lccc}
\hline $\begin{array}{l}\text { Konsumsi } \\
\text { Bahan } \\
\text { Kering }\end{array}$ & \multicolumn{3}{c}{ Perlakuan } \\
\cline { 2 - 4 } & $\mathrm{P} 1$ & $\mathrm{P} 2$ & $\mathrm{P} 3$ \\
\hline $\begin{array}{l}\text { Hijauan } \\
(\mathrm{H})\end{array}$ & 1,32 & 1,43 & 1,68 \\
$\begin{array}{l}\text { Konsentra } \\
\mathrm{t}(\mathrm{K})\end{array}$ & 4,56 & 3,79 & 2,73 \\
\hline $\begin{array}{l}\text { Total } \\
\text { Ransum } \\
(\mathrm{H}+\mathrm{K})\end{array}$ & $\begin{array}{c}5,88 \pm 0,59 \\
\mathrm{a}\end{array}$ & $\begin{array}{c}5,22 \pm 0,48 \\
\mathrm{~b}\end{array}$ & $\begin{array}{c}4,41 \pm 0,12 \\
\mathrm{c}\end{array}$ \\
\hline Keterangan & & & \\
\hline
\end{tabular}

Keterangan: Superscript yang berbeda pada baris yang sama menunjukkan perbedaan yang nyata $(\mathrm{P}<0,05)$

Konsumsi bahan kering ransum pada penelitian ini jika dipersentasekan dengan berat badan ternak sudah mencukupi kebutuhan ternak yaitu untuk P1 3,13\%, P2 2,76\% dan P3 2,30\%. Menurut Kearl (1982), kebutuhan bahan kering pakan yang disarankan untuk sapi pedaging adalah berkisar 2,5-3,0\% dari bobot badan.

\section{Konsumsi Bahan Organik (BO)}

Hasil konsumsi bahan organic (BO) dapat dilihat pada Tabel 2 .

Tabel 2. Data konsumsi bahan organik (BO) hijauan, konsentrat dan ransum (kg/ekor/hari)

\begin{tabular}{lccc}
\hline Konsumsi & \multicolumn{3}{c}{ Perlakuan } \\
\cline { 2 - 4 } $\begin{array}{l}\text { Bahan } \\
\text { Organik }\end{array}$ & $\mathrm{P} 1$ & $\mathrm{P} 2$ & $\mathrm{P} 3$ \\
\hline $\begin{array}{l}\text { Hijauan } \\
(\mathrm{H})\end{array}$ & 1,29 & 1,39 & 1,63 \\
$\begin{array}{l}\text { Konsentra } \\
\mathrm{t}(\mathrm{K})\end{array}$ & 4,30 & 3,58 & 2,57 \\
\hline $\begin{array}{l}\text { Total } \\
\text { Ransum } \\
(\mathrm{H}+\mathrm{K})\end{array}$ & $\begin{array}{c}5,59 \pm 0,56 \\
\mathrm{a}\end{array}$ & $\begin{array}{c}4,97 \pm 0,46 \\
\mathrm{~b}\end{array}$ & $\begin{array}{c}4,20 \pm 0,13 \\
\mathrm{c}\end{array}$ \\
\hline
\end{tabular}


Keterangan: Superscript yang berbeda pada baris yang sama menunjukkan perbedaan yang nyata $(\mathrm{P}<0,05)$

Hasil analisis ragam menunjukkan bahwa perlakuan berpengaruh nyata terhadap konsumsi $\mathrm{BO}$ ransum $(\mathrm{P}<0,05)$. Hasil uji lanjut menunjukkan bahwa konsumsi bahan organic ransum $\mathrm{P} 1$ nyata tertinggi dan masing-masing perlakuan berbeda nyata. Perlakuan $\mathrm{P} 3$ paling rendah $(\mathrm{P}<0,05)$. Hasil penelitian ini menunjukkan bahwa seiiring dengan meningkatnya level pemberian konsentrat berbasis lumpur sawit fermentasi, mensuplai ketersediaan bahan organic yang lebih tinggi. Bahan organic sebagian besar terdiri dari komponen karbohidrat, protein dan lemak yang merupakan sumber energy untuk kehidupan ternak (Parakkasi, 1995).

\section{Kecernaan Bahan Kering dan Bahan Organik Ransum}

Kecernaan bahan kering dan bahan organic ransum dapat dilihat pada Tabel 3.

Tabel 3. Kecernaan Bahan kering dan Bahan Organik Ransum selama penelitian

\begin{tabular}{|c|c|c|c|}
\hline \multirow[t]{2}{*}{ Peubah } & \multicolumn{3}{|c|}{ Perlakuan } \\
\hline & P1 & P2 & P3 \\
\hline $\begin{array}{l}\text { Kecernaa } \\
\text { n Bahan } \\
\text { Kering } \\
(\mathrm{BK})(\%)\end{array}$ & $\begin{array}{c}73,14 \pm 6 \\
30^{\mathrm{a}}\end{array}$ & $\begin{array}{c}69,87 \pm 4,7 \\
7^{\mathrm{ab}}\end{array}$ & $\begin{array}{c}64,94 \pm 3,7 \\
8^{\mathrm{b}}\end{array}$ \\
\hline $\begin{array}{l}\text { Kecernaa } \\
\text { n Bahan } \\
\text { Organik } \\
(\mathrm{BO})(\%)\end{array}$ & $\begin{array}{c}75,15 \pm 5 \\
47^{\mathrm{a}}\end{array}$ & $\begin{array}{l}71,93 \pm 4,8 \\
7^{\mathrm{ab}}\end{array}$ & $\begin{array}{l}66,76 \pm 2,7 \\
5^{\mathrm{b}}\end{array}$ \\
\hline
\end{tabular}

Keterangan: Superscript yang berbeda pada baris yang sama menunjukkan perbedaan yang nyata $(\mathrm{P}<0,05)$

Hasil analisis ragam menunjukkan bahwa perlakuan berpengaruh nyata terhadap kecernaan bahan kering dan bahan organik ransum. Hasil uji lanjut menunjukkan bahwa kecernaan bahan kering dan bahan organic untuk P1 dan P2 berbeda tidak nyata $(\mathrm{P}>0,05)$. Kecernaan $\mathrm{P} 1$ tertinggi dibanding perlakuan lainnya, sedang kecernaan P3 paling rendah $(\mathrm{P}>0,05)$. Kecernaan $\mathrm{BK}$ dan $\mathrm{BO}$ antara $\mathrm{P} 2$ dan $\mathrm{P} 3$ berbeda tidak nyata $(\mathrm{P}<0,05)$.
Nilai kecernaan BK dari ketiga perlakuan tersebut berkisar $64,94-73,14 \%$ dan kecernaan bahan organic berkisar $66,76 \%-75,15 \%$. Nilai kecernaan ini menunjukkan hasil yang baik dan nilai yang tinggi. Hal ini sebagaimana dikatakan oleh Schneider dan Flat (1975) bahwa kecernaan yang tinggi bila nilai nya 50-70\%. Endrawati et al. (2010) melaporkan sapi yang diberi pakan rumput gajah dan konsentrat memiliki nilai kecernaan bahan kering dan kecernaan bahan organic sebesar $65,36 \pm 2,19 \%$ dan $67,10 \pm 2,15 \%$. Dengan demikian pemakaian konsentrat berbasis lumpur sawit fermentasi tidak berdampak negative terhadap kecernaan ransum. Nilai kecernaan ini dapat menjadi tolok ukur dalam menilai kualitas ransum (Sutardi, 1980).

\section{KESIMPULAN}

Pemberian pakan konsentrat berbasis lumpur sawit dan beberapa bahan local yang difermentasi sampai taraf $10 \mathrm{~kg}$ dapat meningkatkan konsumsi dan kecernaan ransum

\section{DAFTAR PUSTAKA}

Direktorat Jenderal Perkebunan. 2014. Statistik Perkebunan Indonesia. Komoditas Sawit Tahun 2011-2013. Direktorat Jenderal Perkebunan, Kementerian Pertanian. Jakarta.

Endrawati, E., Endang,B., Subur, P.S.B. . 2010. Performans induk sapi silangan Simmental-Peranakan Ongole dan induk sapi Peranakan Ongole dengan pakan hijauan dan konsentrat. Buletin Peternakan. 34(2):86-93.

Kearl, L.C. 1982. Nutrient Requirement of Ruminant in Developing Countries. International Feedstuff Institute Utah Agricultural Experiment Station. Utah State University. Logan. Utah.

Lekito, M.N. 2002. Analisis kandungan nutrisi lumpur minyak sawit (Palm Oil Sludge) asal pabrik pengolahan di Kecamatan Prafi Kabupaten Manokwari Propinsi Papua. Jurnal Peternakan dan Lingkungan. Vol.08 No.1. Februari 2002. Hal. 59 -62. 
Mathius, I.W, A .P . Sinurat, D. M. Sitompul, B .P .Manurung dan Azmi. 2005 Pemanfaatan produk fermentasi lumpur-bungkil sebagai bahan pakan sapi potong. Dalam: Prosiding Seminar Nasional Teknologi Peternakan dan Veteriner. Bogor . September 2005.

Mathius, I.W., Azmi, B.P. Manurung, D.M. Sitompul dan E.Pryatomo. 2004. Integrasi Sawit-Sapi: Imbangan pemanfaatan produk samping sebagai bahan dasar pakan. Prosiding Sistem Integrasi Tanaman-Ternak. Denpasar. Juli 2004. Hal : 439-446

Schneider, B.H. and W.P. Flatt. 1975. The Evaluation of Feeds Through Digestibility Experiment. The
University of Georgia Press, New York.

Sutardi, T. 1980. Landasan Ilmu Nutrisi. Jilid 1. Departemen Ilmu Makanan Ternak. Fakultas Peternakan.

Utomo, B. N. dan Widjaja, E. 2004. Limbah padat pengolahan minyak sawit sebagai sumber nutrisi ternak ruminansia. Jurnal Litbang Pertanian. 23(1). Hal:22-28.

Wina, E. 2005. Teknologi pemanfaatan mikroorganisme dalam pakan untuk meningkatkan produktivitas ternak ruminansia di Indonesia: Sebuah Review. Wartazoa. 15(4): 173-186.

Winarno, F. G. 1992. Pengantar Teknologi Pakan. Gramedia. Jakarta 